\title{
Disrobing and Redressing Sex
}

\author{
Geoffrey Guevara
}

\begin{abstract}
This research is a precursor to further studies on socio-cultural issues such as reproductive health, homosexual marriages, infidelity and teenage sexuality. With the goal of creating a framework for a resolution to these issues, the author focuses on sex as the central question. Progress in debates on these issues and the general ethos depend on people's attitude towards sex. In the Philippines, sex unfortunately remains in the cloister of morality and marital obligations, despite changes in time and social needs. Though the virtues of chastity and fidelity remain important, this author suggests a frame outside morality and Christian duty through which sex can be appreciated. The author uses the lenses of philosophy, particularly Max Scheler's non-formal ethics of values, with supporting insights from the development psychologist, Evelyn Eaton Whitehead and her husband, James, a pastoral theologian, to reframe how sex is viewed. The author's thesis is that sex is good and, when done properly, can be a vehicle for human persons to touch the fundamentals of their finitude and the glory of their existence.
\end{abstract}

KEY WORDS: human person, philosophy, Max Scheler, sex, sexuality, values

The philosopher Max Scheler (1874-1928) describes love as the movement from a lower value to a higher value. Scheler avoids romanticizing love as limited to relationships or the other-worldly. Instead, he includes in his discussion even the trivial-from falling in love when one first catches sight of the beloved, to the deep and eternal divine love shared in communal and religious experiences. For Scheler, love is about values and values being present in all things makes it possible to speak of anything as the object of and vehicle for love.

It is in this light that I want to focus on the sexual act as a source and expression of love. Often we hear sex referred to as love-making. 
In movies, we find characters getting in bed after a romantic date or a dramatic reconciliation to dramatize the intensity of their love and the deepening of their relationship. Indeed this is love-making, translating into the physical what is utterly beyond for the beyond. Yet this portrayal, viewed by the unreflecting, may send a counter-productive message. Sex may be misunderstood as the test and summit of true love. And so it is not extraordinary that we hear of young couples, especially adolescents in their teenage hormonal rage and puppy love, falling into the trap of engaging in sex, thinking sex proves their love for their partner. And then slide down we go from unwarranted sex to unwanted pregnancies to the extreme, casual sex, sex for fun.

These realities have stripped from sex the dress of love in which it used to be clothed. Though it is true that sex is carnal, that is, of the body, to be pigeonholed to only the carnal and or be spoken of only within the confines of committed relationships sealed in marriage diminishes and destroys the potency of sex to unite and create persons-which is, precisely, love. Can we not therefore speak of sex as love? Must sex be always viewed as something dirty and be hidden under the sheets in darkness? For Scheler, it is possible to rehabilitate the potency of sex by framing it in the order of values.

\section{SEX AND VALUES}

Scheler believes in the special relationship of human persons and values. Values ride on the back of goods (Formalism in Ethics 13) and the human person is drawn by these values. Even without knowledge of this realm and its movement, the human person is deeply affected by values, which makes the person act in certain ways. Choice and one's actions are dependent on the value that catches one's heart. Curiously, a particular object or action hosts different values. It is only the person who can decipher what value he/she is responding to, by being sensitive to the nuances of the accompanying feelings of attraction.

This dynamic is peculiar to Scheler's phenomenology. Whereas other philosophers ascribe the acts of individuals to reason, Scheler speaks of the primary movement of the heart-that for the person there is first a fastening onto a value, followed by a response. He focuses on the affective instead of the logico-cognitive apparatus of the brain. This human faculty is responsible for the seemingly irrational acts chosen and done by human persons. A person, seeing (or, more appropriately, feeling) the value of an act, pursues the object of affection, however illogical or absurd (Formalism in Ethics 255). This is a very important insight Scheler introduces, opening 
up the field of discussion to non-rational acts, or to acts which follow a different order. Scheler's phenomenology brings to the surface that aspect of choice which seems irrational-at least to rationalists-but really is not. He asserts that the order of values follows a different kind of rationality. Scheler calls this order logique du coeur, the "logic of the heart," borrowing from Blaise Pascal (Formalism in Ethics 254).

Scheler, reflecting on the ordinary everyday experience of human valuation, notices four tendencies in human choices. First, humans prefer something that will last longer than that which is fleeting and temporary. Second, that which can be shared by more without diminishing the item is found to be more valuable. Third, humans long for that which provides deeper satisfaction and greater fulfillment. And finally, that which opens the doors to the more is preferred over that which limits the individual to a particular (Frings 31-33). These four tendencies have become the basis for Scheler's arrangement of the different manifestations of value. He arranges the values in a ladder from the least valuable to the most valuable as illustrated below:

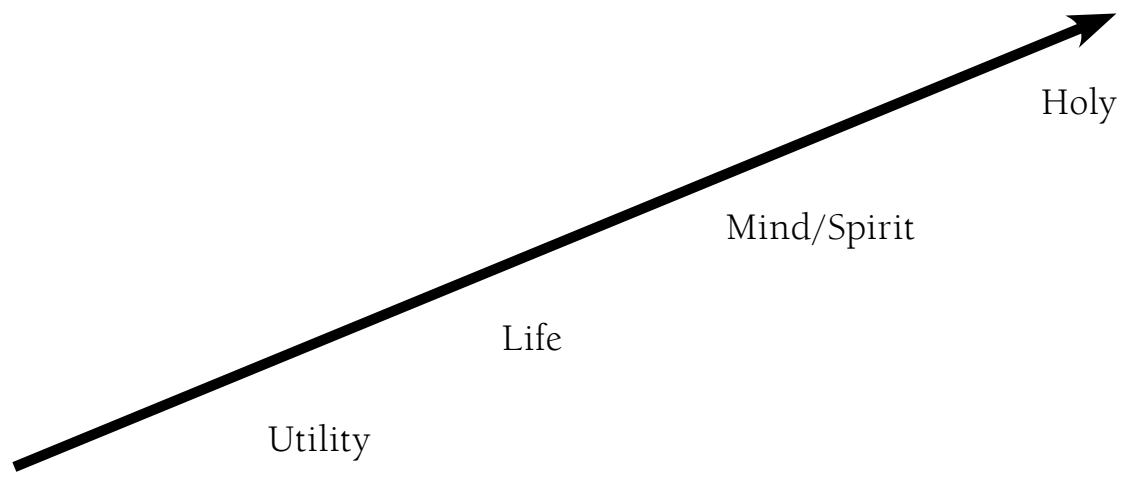

Sensible

For Scheler, all these values permeate a single deed, in our case, sex (Formalism in Ethics 22). "Every good represents a small 'hierarchy of values"' (20). In sex, we can find the values of the sensible, utility, life, mind/ spirit, and the holy, experienced and expressed uniquely by different people. Without going into ethics just yet, the following is how Scheler described the kinds of sexual intercourse according to value. Of the lowest value is the sensible: "sexual intercourse which aims at the pleasure of the flesh" (Frings 94). Individuals see sex as something from which they can derive pleasure. Sex is treated as a reaction to libido, something that can 
satisfy the carnal desires of the person. Next is the kind "that only uses the partner" (Frings 94). This is related to the first, but this kind has the beginnings of a relationship. Though it may be transactional and/or temporary in nature, this is higher than the first because it recognizes persons as elements of the intercourse. This is usually seen in sexual intercourse with men or women for pay, or with "fuck buddies" or "one night stands." Third, related to the value of life, is sexual intercourse directed toward the bringing forth of offspring. This is the kind of intercourse promoted by most Christian churches. Sexual intercourse, in this case, should always be seen in the context of begetting children and creating a family. The fourth kind, which Scheler calls a "rare type," is in the realm of holy value. He describes this in his discussion of heterophatic emotive identification in the first part of the book The Nature of Sympathy: ${ }^{1}$

The most elementary form of this is certainly to be found in truly loving sexual intercourse (i.e. the opposite of sensual, utilitarian, or purposive act), when the partners, in an impassioned suspension of their spiritual personality (itself the seat of individual self-awareness), seem to relapse into a single life-stream in which nothing of their individual selves remains any longer distinct, though it has equally little resemblance to a consciousness of 'us' founded on the respective self-awareness of each. (25)

Rich with insight on sexual intercourse, we shall unpack this and carefully examine the meaning of Scheler's words in the sections below.

\section{Sex is Good}

Because Scheler acknowledges the existence of values and the unique apprehensions of values by individuals, Scheler's ethics deviates from the categorical and formal ethics of the rationalists. On one hand, his ethics takes into account the historical situatedness of the human person and the ethos of the individual person. On the other hand, there is the objective order of values to which the human person subscribes. Scheler admits

${ }^{1}$ In this book, Scheler uses the example of sex to illustrate the kind of togetherness or emotional unity he wishes to see in a collective. In an heteropathic emotive identification (as opposed to idiopathic emotive identification where one absorbs the other and loses one's individual identity), the "I' (the formal subject) [is] so overwhelmed and hypnotically bound and fettered by the other 'I' (the concrete individual), that [his/her] formal status as a subject is usurped by the other's personality, with all its characteristic aspects; in such a case, [he/ she] live[s], not in ['him/herself'], but entirely in 'him', the other person-(in and through him, as it were)" (The Nature of Sympathy 19). In other words, as the "I" sees the other in oneself, he/she does not lose his/her own self. 
that individuals may find themselves being attracted to a particular lower value but, at the same time, they cannot escape the pull of the desire for what is deeper, broader, and eternal, i.e. the higher value. The response to be moved to fulfill the higher value is good. This is what Scheler says about good and evil:

The value "good"-in an absolute sense-is the value that appears, by way of essential necessity, on the act of realizing the value which (with respect to the measure of cognition of that being which realizes it) is the highest. The value "evil"-in an absolute sense-is the value that appears on the act of realizing the lowest value.... the value "good" is the value that is attached to the act which realizes a positive value, as opposed to a negative value, within the higher (or highest) level of value-ranks. The value "evil" is the one that is attached to the act which realizes a negative value. $^{2}$ (Formalism in Ethics 25-26)

Applied to sexual intercourse then, it is an inescapable fact that sex provides gratification to sexual partners. At face value, it fulfills the lowest value, the sensible, but this does not automatically mean that when partners take pleasure in sex, sexual intercourse is already evil. On the contrary, even if sexual intercourse is at first seen as partaking in pleasure, it is still positive and therefore, good.

But before readers indulge in sex for pleasure alone, we return to the primary criterion: sexual intercourse beckons the sexual partners to take note of the higher values for them to actualize. It is the openness of individuals to the movement towards the higher values which makes sexual intercourse good. He says,

Pleasure should not be the primary aim, and it is only as a by-product of love-making, not as a goal and object, that it attains a depth and power of passion sufficient to produce a genuine fusion and identity of feeling. If the pleasure pursued is entirely self-centered, the phenomenon of fusion and identification is invariably absent. The partner then becomes simply a means of auto-erotic satisfaction. (The Nature of Sympathy 111)

\section{Sexual Intercourse and Procreation}

Sexual intercourse, as fulfilling the holy value, is a recreation of the higher dynamic principle of creation (The Nature of Sympathy 112-3). Scheler's reference to "creation" is not necessarily about procreation or

${ }^{2}$ Positive and negative traits to values refer to the existence or non-existence of a value. 
the bearing of children. What he says is that the deep sharing of sexual partners in love is in itself already a replication of Divine Love, with or without offspring. Sexual intercourse stems from love, that is to say, the fulfillment of values and the movement to the higher values.

Scheler vehemently rejects treating sex as a means to an end, the end being the propagation and extension of life and population. Though he admits that sexual love "can be no more than the finest flowering, the absolute climax, summit and peak of man's career as a vital being," it cannot be "enlisted in the service of practical life, society, the state (war), the nation, commercial life even. .." (The Nature of Sympathy 114). In the same work, he further adds that "the qualitative peak of organic life cannot be subordinated to the mere quantitative multiplication of human lives" (115). Couples engage in sexual intercourse not for reproduction but out of love. Sexual intercourse is the finest expression of their union through oneness in experience, in bodily movement, and pleasure. The fruit of sex is the act of love making itself. Begetting children, though it is a positive value and wondrous miracle, is but a gratuitous product, a reproduction of the creative power of the sharing of selves in sexual love.

\section{Rare Type of Sex}

Sexual intercourse is anchored on love. It is not about couples fulfilling their obligations to their partners. Neither is it about keeping a promise they made to God in their marriage, that is, "procreation and upbringing of children" (Code of Canon Law 1055\$1). Sexual union is about giving oneself to the partner and receiving the other. Being embodied subjects, what better way is there to express this giving and receiving, sharing and experiencing each other, than through the body.

For Scheler, authentic sexual intercourse involves two movements: suspension and merging. One is not too conscious of oneself as one gives him/herself in the intercourse. This presupposes, of course, a deep and healthy awareness of the self-one's pleasure points, capacities, and limits. Only in being comfortable in one's skin can someone give oneself to the other in sex. Therefore, to suspend one's self means one is able to engage in sex without thinking too much about what one can gain from it. Neither is it about focusing on the other's pleasure in such a way that sex becomes a performance or a task. "Suspension of the personality" means, in the literal sense, being able to feel the other as much as one feels the self in the sexual act. One feels every fiber, every muscle, the contraction and expansion of the sexual organs as one penetrates the other. 
This is why sexual intercourse, as described in the first section of this essay, is of the holy. The kind of union experienced in the sexual act is something one cannot experience in talk, friendship, or companionship. It is a spiritual sharing-one that exceeds the limits of the body and of chronological time, yet is facilitated and felt by the body itself. This is the second movement of sexual intercourse: merging. After gaining a heightened awareness of each other, partners are able to give up their selves and join into one life-stream. Sexual partners become one in the act, and the literal configuration of the body demonstrates this oneness. As the sexual partners are in each other, the two separate bodies are joined together in an intimate embrace during "mutual climax."

It is important to take note of the word "mutual" above. "Mutuality" is not limited to simultaneous ejaculation or orgasm, although it does not preclude it either. It simply means that the sexual partners get to a level of heightened openness to each other-the shivers of the body included. "Mutual climax" is what bridges the two separate and distinct individuals unraveling their intimate selves to each other.

What makes this act holy is that in the unfolding of the partners' intimate selves, they remain separate individuals-separate yet together, distinct yet one. Scheler calls this relationship the heteropathic emotive identification or mystical union (The Nature of Sympathy 127). A play on the Filipino word for genitalia can elucidate Scheler's point. In Filipino, the genitals are called ari, the root of words that are cognates for the English word "possession." In the act of sex, the ari of the couples are shared with each other, as if their possessions are given to the other. In spite of this sharing however, their ari cannot be possessed or owned by the other ("hindi maa-ari")-given but cannot be owned, one yet distinct. This is the sacredness of the sexual act-something each couple should aspire to fulfill in every sexual encounter.

\section{Sex as Giving and Receiving}

Scheler's rare type of sex does not dismiss as without value each and every other act of sexual intercourse that does not fulfill the description. Rather, he simply wants to show what the value of sexual intercourse is and the realm each sexual partner enters everytime they engage in the act. His point is that every sexual partner must strive toward the rare type of sex by giving and receiving each other in the intimacy of the act. Whether or not they reach that level of intimacy, the goodness of sex lies in the partners' willingness to realize the value of sex, their partners and their selves. 
Scheler's position on sex is echoed in the new theology of sexual intercourse propounded by Evelyn Eaton Whitehead and her husband, James D. Whitehead. Their works, though separated from Scheler's by at least fifty years-uncannily run parallel to each other. The following are the salient points raised by the Whiteheads about sex, which are very similar to Scheler's:

What is the truth that we, the Christian body, find in our sexual experience? We discover, first, the goodness of sexual arousal itself. This stirring in our bodies is one of the roots of our creativity; it draws us to others; it ignites the attraction that sustains the fruitful commitments of life-in friendship, in marriage, in devoted life. Second, we recognize that sexual love has more to do with fruitfulness than with fertility. Sex is, with its unexpected awakenings and unearned delights, an echo of creation. Third, we realize that in the touches and strokes of sexual sharing we are revealed to ourselves; we are brought to see a loveliness that we had been incapable of imagining on our own. And finally, we know that in our sexual lives we often find spiritual healing. Our physical embraces soothe old wounds and make forgiveness tangible. In the intimacy we share with a sexual partner, the reality of God's goodness and forgiveness finally becomes more than rhetoric. As lovers, we give thanks for this grace. (A Sense of Sexuality 25-26)

Sexual intercourse is really more about developing a real, concrete relationship rather than simply pleasure-seeking or child-making. Sexual intercourse, for the Whiteheads, "has more to do with fruitfulness than with fertility" (34), a point that echoes Scheler. Fruitfulness is where we hope to frame our understanding and appreciation of sex. Sexual intercourse as an act of giving and receiving is an act of bearing fruit, of creation-creating stronger bonds, deeper relationships, more expansive knowledge of the other and the self-which further develops the individuals in the relationship. When one freely and wholly offers oneself to the partner, one is able to receive the other into one's own self. In the mutual giving and receiving, the sharing and partaking of selves, the couples open themselves up to the absolute as well. Their union is no longer only about themselves but a union with the cosmos. At the rapture of intense pleasure, they catch a sight of the wonderful world of values and the eternal possibilities. As Scheler says,

Let this be granted: and let it be conceded also that man's sense of unity with the living cosmos is in general so bound up with the sense of union 
in sexual love that the latter is, as it were, the 'gateway' to the former; for it is not so much the foundation thereof as the means, prescribed by Nature herself, of arousing in man a capacity for identification with the cosmos, which is not in itself, at all dependent upon sexual love. (The Nature of Sympathy 127)

\section{LOVING SEX}

Sex therefore is a very real and concrete expression of love. Is sex to be shared by married couples alone? Is it exclusively for the committed and those blessed by the Church? Is it only for those ready to bear children? Faced with these questions, the more fundamental question to ask is the question of love: Are those engaging in sex coming from love? If they are, it is inherent that the sexual act is fueled by their response to the call of values and in openness to the creative process, being one with each other and the cosmos. The questions above-of sex before or after marriage, and the like-cease to be a problem when viewed through the lenses of love. Sex, if driven by love and done for love, will always be done responsibly, with dignity and passion.

It will be done responsibly, because it involves foresight and preparation for the consequences of the sexual intercourse. Such consequences include but are not limited to the begetting of offspring and the possibility of being fixated on the merely physical, as in the case of juvenile sex. It will be done with dignity because it involves persons bearing values. Wild, adventurous, kinky sex can enhance sexual relations but, without care, it can hurt partners both physically and emotionally. It will be passionate because a total giving of the self is necessary in sex. Without the full person involved in the act, sex can become a chore aimed at fulfilling sexual and/or marital obligations. In that case, sex can even be the cause of couples drifting apart.

Sex, like any other good, is a movement from a lower value to a higher value. Sex as the expression of love, enjoys the pleasures of carnality, the lowest value, and also celebrates the wonders of giving and receiving in the union of bodies and spirits, the highest value of the holy. Because sex is love, the persons engaged in sex are changed as they give of themselves, renewed as they receive their partners, and made whole as they catch a glimpse of eternal oneness in the suspension of their selves in climax.

Sex is sacred and must be rightfully valued as such because it is the only activity which exposes and unites the intimate aspects of individuals. Sexual intercourse is not just about bodies cavorting or cells fertilizing. It 
is about spirits communicating that which cannot be uttered by words and that which cannot be intuited in silence. Sexual intercourse is special in this way and more, because it elevates the individuals in a kind of mystical union in the suspension of time, in the explosion of mutual giving. Sex brings the finite to the level of the infinite in the total giving and receiving of each other in sexual love.

It is unfortunate that conservative societies cannot appreciate sex this way. And it is not without reason that sex is pigeonholed to the crass and worldly because quite a number of people played with and remained at the lower values that accompany the act of sex. Hence the admonition to keep sex within the limits of the marital promise to ensure that promiscuity is kept at bay and the value of life is at least fulfilled. Scheler and the Whiteheads try to allay our fears by reminding us of the rare type of sex and the concept of fruitfulness. All sex, if done in love, is not and can never be immoral, because sexual partners know the value of sex and the value of their sexual partner. Sexual activity is the fruition of the holy and a personal experience of the being of values. Sex is good-something to be revered and, at the same time, relished. If only it can be discussed more in the open, so that the fear of sex and the bad credit it has acquired through the years would be erased.

Sex is human-very human-especially when done with love as its intent. Rare sex is a profound expression of our humanity and transcendence. Humans touch the base of their finitude at the sight of their nakedness and become infinite in the exchange of intimate depth and profundity in the intercourse with another naked, finite person. This is special to humans-that they can copulate pleasurably and meaningfully. With love at the core, sex is a powerful unifier with the self, with the partner, and with the cosmos. The famous adage goes, "love is the answer." I say, so too is sex.

\section{WORKS CITED}

Frings, Manfred S. The Mind of Max Scheler: The First Comprehensive Guide Based on the Complete Works. Milwaukee: Marquette UP, 1997. Print.

Scheler, Max. Formalism in Ethics and Non-Formal Ethics of Values: A New Attempt toward the Foundation of an Ethical Personalism. Trans. Manfred S. Frings and Roger L. Funk. Evanston: Northwestern UP, 1973. Print.

---. The Nature of Sympathy. Trans. Peter Heath. Hamden, CT: Archon, 1970. Print.

Whitehead, Evelyn Eaton and James D. Whitehead. A Sense of Sexuality: Christian Love and Intimacy. New York: Crossroad, 1994. Print.

Roman Catholic Church. Code of Canon Law. Libreria Editrice Vaticana, 4 Nov. 2003.

Web. 16 May 2012. 
Geoffrey Guevara has been with the Philosophy Department of Ateneo de Manila University since 2000. He began as a Teaching Assistant to the Metrobank Foundation Outstanding Teacher Awardee, Dr. Manuel B. Dy, Jr. while studying for his master's degree in Philosophy. In 2005, he successfully defended his thesis on the place of human persons in a multicultural world, drawing inspiration from his experience as a Jesuit Volunteer in Miarayon and Cabanglasan, Bukidnon. He continues his research on multiculturalism, now angled on God, religion, and society. He plans to start writing his PhD dissertation on this subject in the next school year, and finish soon after to have more time for more books, research, the kitchen, and his dear wife. 